\title{
Influence of Lightweight Concrete Block Support on Physical and Mechanical Characteristics of Applied Mortars
}

\author{
Dora Silveira $^{1}$, Isabel Torres ${ }^{2}$, Inês F. Colen ${ }^{3}$ and Rafael T. Pinto ${ }^{4}$ \\ ${ }^{1}$ Itecons, ADAI-LAETA, dora.silveira@itecons.uc.pt \\ 2 DECivil, ADAI-LAETA, Itecons/University of Coimbra, itorres@dec.uc.pt \\ ${ }^{3}$ CERIS, DECivil, IST, University of Lisbon, ines.flores.colen@tecnico.ulisboa.pt \\ ${ }^{4} \mathrm{PhD}$ student, DECivil, University of Coimbra, Research fellow, IST, rafaeltravincas@gmail.com
}

\begin{abstract}
The objective of the present work is to analyze the influence of the lightweight concrete block support on the physical and mechanical characteristics of the applied mortar. This work aims to understand how the physical and mechanical properties of the mortar are modified by the support. The methodology used consisted of conducting laboratory experimental tests to compare the behavior of mortar molded in standard moulds with the behavior of mortar applied to lightweight concrete block supports. Open porosity, bulk density, capillary water absorption, water vapor permeability and compressive strength were studied. These results have shown how the support influences the characteristics of the mortar, improving the understanding of the performance of the applied mortar. This study provides a global approach to the assessment of mortar characteristics, considering the analysis and comparison of mortar applied to the support and molded in the laboratory, according to current standards. Such understanding may contribute to the reassessment of the way mortars are produced, seeking to optimize their characteristics and compatibility with the support.
\end{abstract}

Keywords: Mortar, Support, Performance, Lightweight Concrete Block.

\section{Introduction}

Coating mortars have an important role in protecting buildings from degradation agents (FloresColen, 2016). One of the most important in-service degradation agents is water, which can lead to physical, chemical and, in some cases, mechanical deterioration (Addleson, 1991). Thus, the performance of coating mortars is influenced by water capillary absorption, hygroscopic moisture content, water permeability, diffusion of water vapor, porosity, soluble salts content and propensity for the growth of microorganisms (Flores-Colen, 2013).

Therefore, it is very important to ensure the quality of the applied mortars, as they contribute significantly to the durability of buildings. For this, it is important to use mortars that are compatible with the supports and that will ensure adequate protection to the building. Thus, low water permeability, good water vapor permeability, good adhesion to the substrate, deformation capacity, among others, are sought (LNEC, 1968; Flores-Colen, 2009; Martins, 2008; Arromba, 2011).

The influence of different factors on the behavior of mortars, such as the quality of the binder, aggregate particle size, water-binder ratio, application conditions, and dosage, have been extensively studied (Torres, 2014; Veiga, 2005; Veiga, 1998; Valente, 1996). However, there are still few studies on the influence of the support on mortar characteristics (Torres, 2014). This work aims to contribute to this knowledge. 
This research intends to identify how the lightweight concrete block support influences the performance of the applied mortar, considering that the applied mortar is in different conditions than those of mortars hardened in laboratory molds. Thus, the understanding of the characteristics of the applied mortar and the possibility of creating a correlation with the characteristics of the mortar hardened in laboratory molds, may enable a greater compatibility of the mortar with the support and provide data for the optimization of mortar composition. Such understanding may help to increase the in-service durability of mortars.

\section{Materials and Methods}

\subsection{Materials}

In this experimental campaign, the following materials were used: lightweight concrete blocks, with Leca expanded clay aggregates, with dimensions of $50 \times 20 \times 10 \mathrm{~cm}^{3}, \mathrm{CEM}$ II / BL $32.5 \mathrm{~N}$ cement and sand with well-distributed granulometry. For the cement mortar preparation, a cement/sand ratio of 1:4, in volume, and a water/cement ratio of 1:1, in weight, were used.

\subsection{Methodology}

A laboratory experimental campaign was carried out, for the comparison of the characteristics of the cement mortar hardened in standard laboratory metallic molds and the characteristics of the cement mortar applied to (and later detached from) lightweight

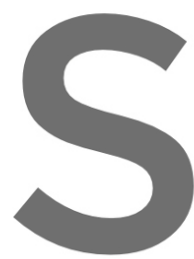
concrete block supports

For the execution standard molds (with d $\mathrm{mm}^{3}$, thus having the same dimensions of the detached.
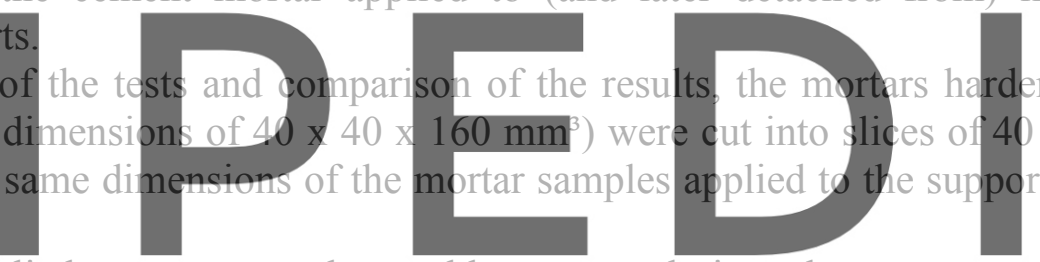

To prepare the applied mortars, wooden molds were made in order to ensure a constant

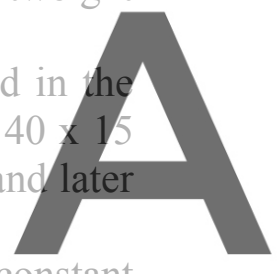

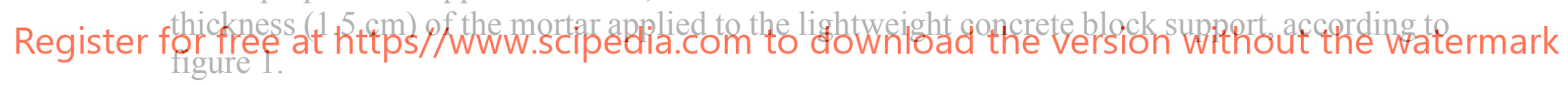

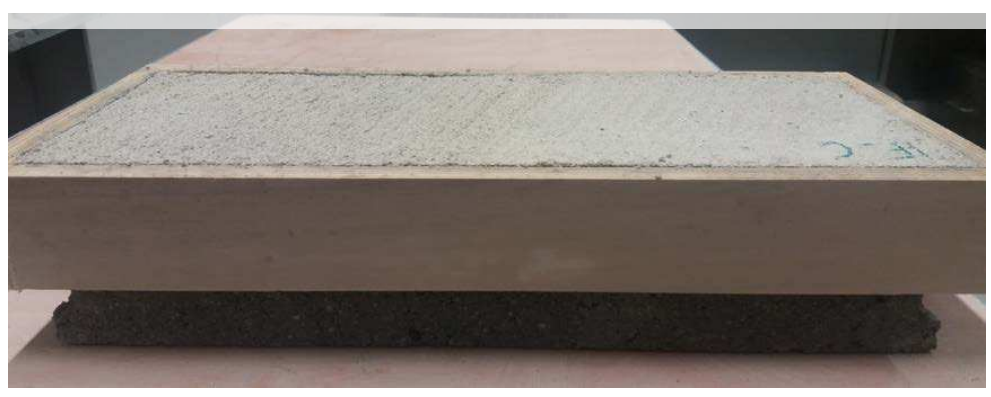

Figure 1. Lightweight concrete block with wooden frame and applied mortar.

As an initial step, the bricks were dried until mass stabilization, and, before applying the cement mortar, each support was wetted by spraying $100 \mathrm{ml}$ of water. 
The tests were performed after 28 days of curing. The curing was carried out according to the indications of EN 1015-11: 1999, both for the mortar hardened in the molds and for the mortar applied to the supports. The curing conditions were as follows:

- First 2 days: temperature of $20^{\circ} \mathrm{C}+/-2^{\circ} \mathrm{C}$, inside of a polyethylene bag (in the mold);

- Next 5 days: temperature of $20^{\circ} \mathrm{C}+/-2^{\circ} \mathrm{C}$, inside of a polyethylene bag (demolded);

- 21 days remaining: temperature of $20^{\circ} \mathrm{C}+/-2^{\circ} \mathrm{C}$, relative humidity of $65 \%+/-5 \%$ (without the mold).

The tests carried out in this experimental campaign are listed in table 1 . The results presented in the following sections refer to the average of results obtained in tests carried out on three specimens.

Table 1. Tests conducted and standards followed.

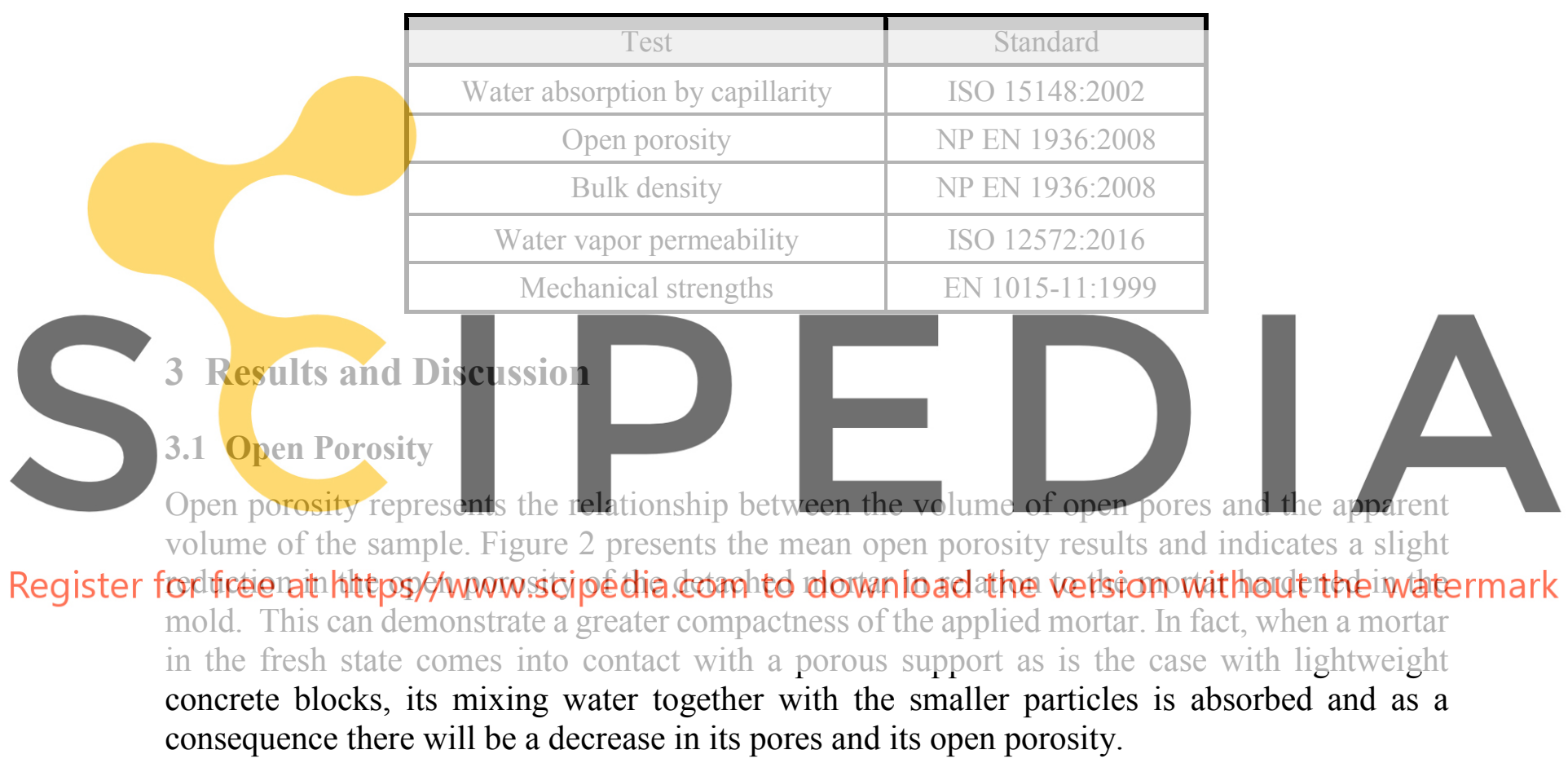

\subsection{Bulk Density}

The determination of bulk density by the geometric method reflects the simple relationship between the dry mass and the apparent volume (including all voids) of a sample. Figure 3 shows a slight increase in the mean density of the mortar detached from the support in relation to the mortar hardened in the mold, which is consistent with the reduction of the open porosity. 


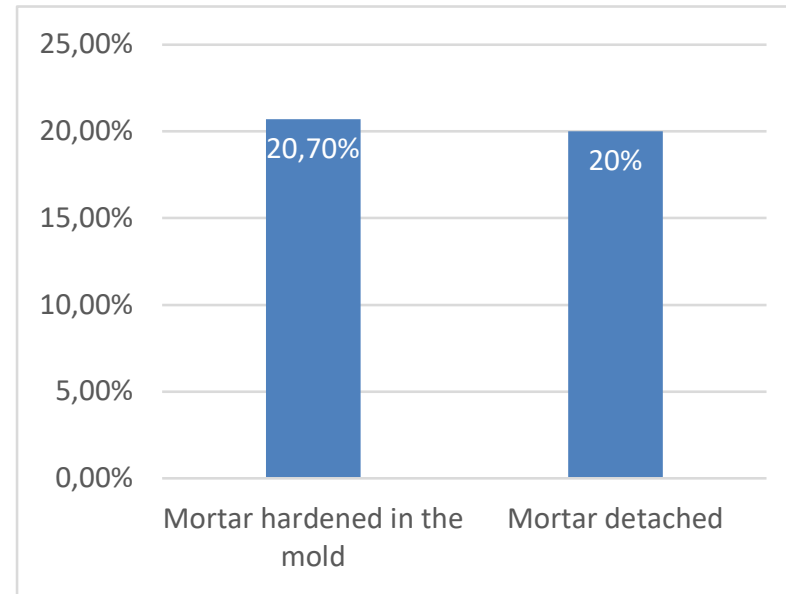

Figure 2. Open porosity.

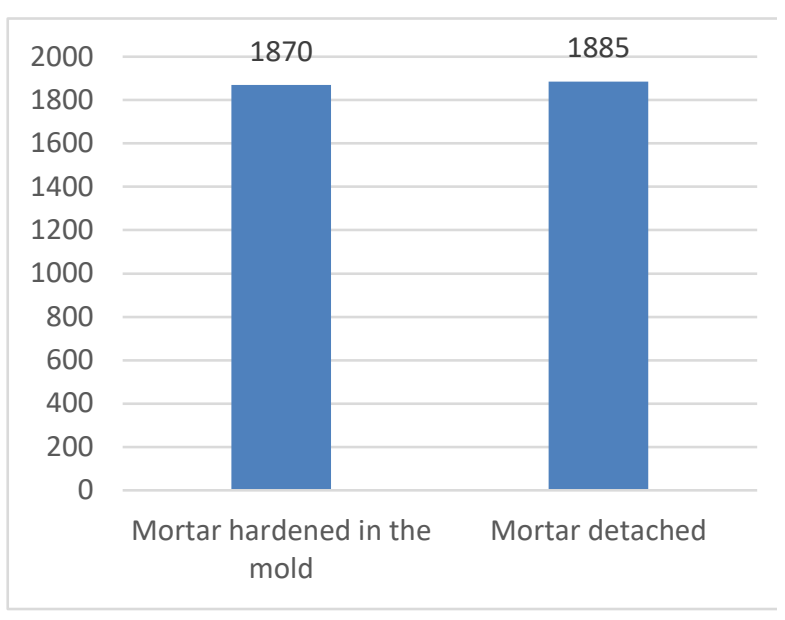

Figure 3. Bulk density $\left(\mathrm{kg} / \mathrm{m}^{3}\right)$.

\subsection{Capillary Water Absorption}

The water absorption coefficient provides an indication of the water-absorbing capacity of a mortar when placed in contact with a water film.
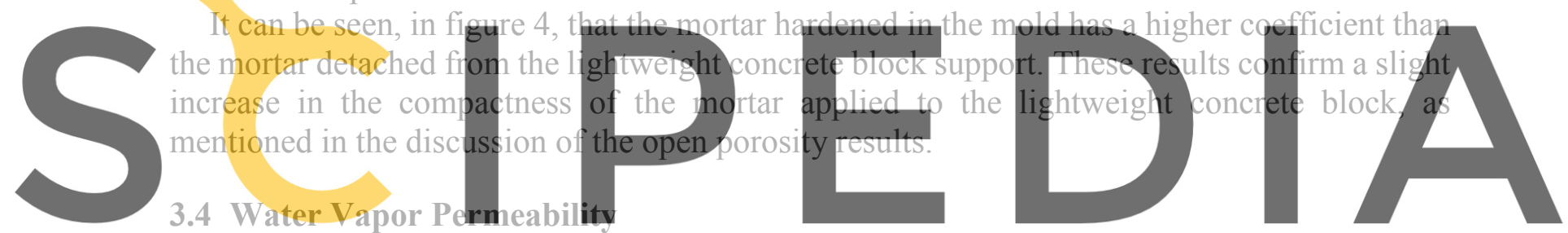

The water vapor permeability coefficient reflects the ability of a material to be traversed by

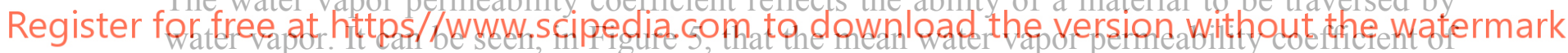
the detached mortar is lower than that of the mortar hardened in the mold - such a result demonstrates a greater resistance to the passage of water vapor by the detached mortar in relation to the mortar hardened in the mold.

\subsection{Compressive Strength}

Figure 5 shows the mean results obtained in the compression test and indicates that the mortar hardened in the mold presented a slightly higher compressive strength in relation to the detached mortar. Although the decrease in open porosity could lead one to think that the mechanical strength would increase, it is possible that this decrease may be due to some weakening that may have occurred when detaching the mortar from the substrate. 


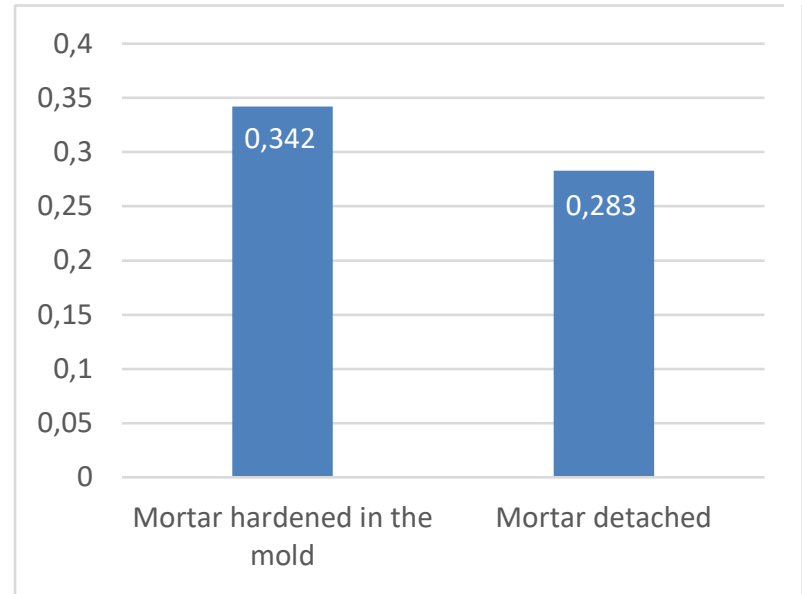

Figure 4. Capillary water absorption coefficient $(\mathrm{kg} /$ $\left(\mathrm{m}^{2} \cdot \mathrm{s}^{0.5}\right)$.

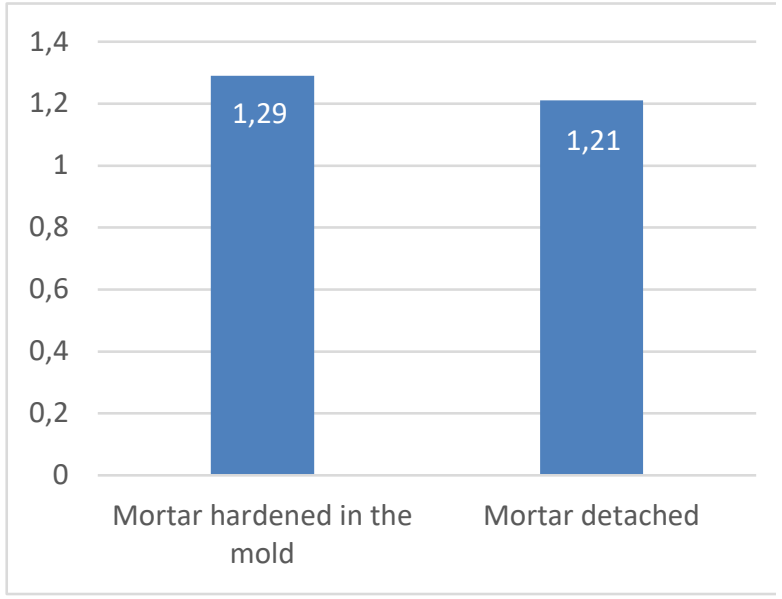

Figure 5. Water vapor permeability coefficient $\left[\left(\mathrm{kg} /(\mathrm{m} \cdot \mathrm{s} \cdot \mathrm{Pa}) \cdot 10^{-11}\right]\right.$.

An expected result face to the obtained results for the characteristics already mentioned.
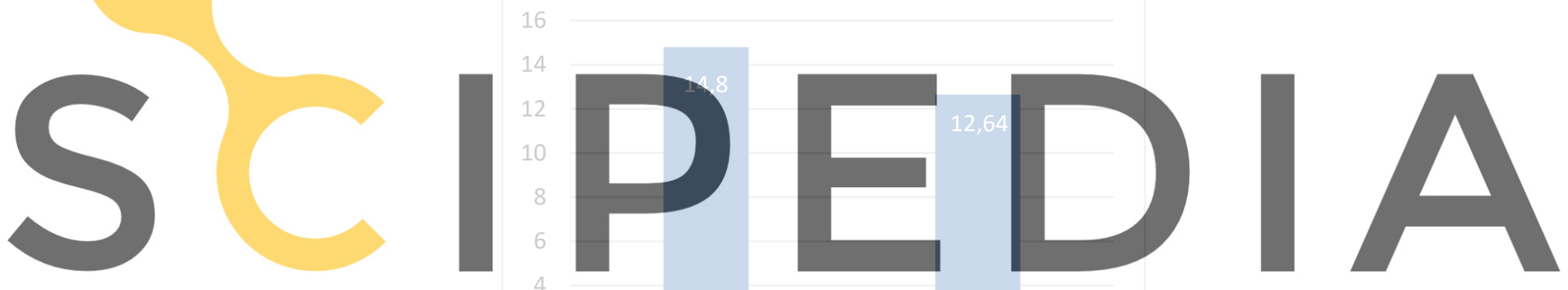

Register for free at https//www.'scipedia.com to download the version without the watermark

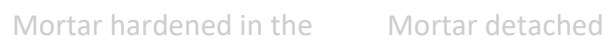

mold

Figure 6. Compressive strength (MPa).

\section{Conclusions}

As a conclusion, it can be observed that the mortar detached from the support has slightly different characteristics in relation to the mortar hardened in the molds; however, it is not clear that these differences are due to the support. The support can influence the characteristics of the applied mortar, as already seen in previous works using the ceramic brick support (e.g. Torres, 2014), however this influence was not significant for the lightweight concrete block.

It can be seen that the mortar applied to the lightweight concrete block is slightly more compact, with less open porosity. Consistently, the lower water absorption and lower water vapor permeability occurred for the mortar applied to the support. Conversely, the compressive strength of the applied mortar is lower than that of the mortar hardened in the mold. 
The influence of the support on the physical and mechanical characteristics of the applied mortar is a relevant issue in relation to performance and durability, and extensive studies on different types of supports and different types of mortar may increase the compatibility of the mortar/support interface.

\section{Acknowledgements}

The work presented was carried out within the framework of the IF MORTAR project (POCI-01-0145-FEDER032223, PTDC/ECI-EGC/32223/2017,), within the scope of the Portugal 2020 program, financed by FEDER through the POCI program. The funding provided is kindly acknowledged. The authors also thank CERIS and CERENA, research units from IST.

\section{ORCID}

Dora Silveira: http://orcid.org/0000-0002-0063-2556

Isabel Torres: http://orcid.org/0000-0002-0515-1743

Inês F. Colen: http://orcid.org/0000-0003-4038-6748

Rafael T. Pinto: http://orcid.org/0000-0002-9059-1232

\section{References}

Arromba, J. (2011). "Influência do suporte no desempenho de rebocos aplicados em suportes de tijolo e betão recorrendo a técnicas de ensaio in-situ". Dissertação para obtenção do grau de Mestre em Construção, Lisboa, Instituto Superior Técnico,

Flores-Colen, I. (2009). "Metodologia de avaliação do desempenho em serviço de fachadas rebocadas na óptica da manutenção predictiya". Tese de Doutoramento em Engenharia Ci

Flores-Colen, I., Silva, performance assessm

I Flores-Colen, J de Brito and 2013. Rotterdam.

L Addleson and C Rice,
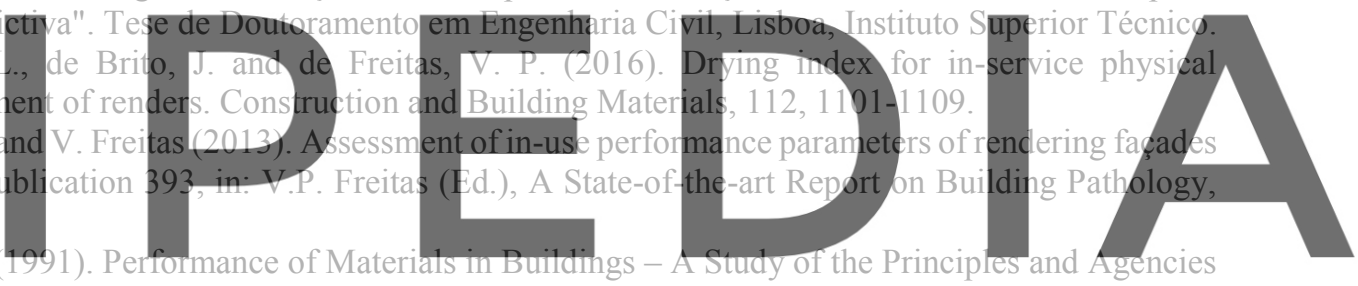
of Change, Butterworth-Heinemann, UK, Oxford, p. 588.

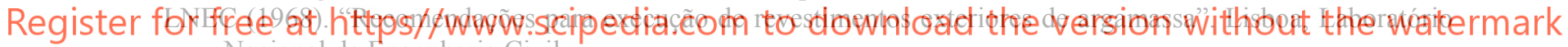
Nacional de Engenharia Civil.

Martins, A. (2008). "Estudo da influência da dosagem de cimento no desempenho de argamassas de reboco". Dissertação para obtenção do grau de Mestre em Construção, Lisboa, Instituto Superior Técnico,

Torres, I. (2014). "Influência da absorção do suporte na argamassa de revestimento" - Relatório de pós doutoramento

Valente, V. (1996). "Caracterização da aderência de argamassas tradicionais em paramentos exteriores constituídos por blocos de betão de argila expandida". Dissertação submetida para satisfação parcial dos requisitos do grau de mestre em Construção de Edifícios, Porto, Faculdade de Engenharia da Universidade do Porto.

Veiga, R. (1998). "Comportamento de argamassas de revestimento de paredes - Contribuição para o estudo da sua resistência à fendilhação". Dissertação para a obtenção do grau de Doutor em Engenharia Civil pela Faculdade de Engenharia da Universidade do Porto, Teses e programas de investigação do Laboratório Nacional de Engenharia Civil Lisboa.

Veiga, R. (2005). "Comportamento de revestimentos de fachadas com base em ligante mineral. Exigências funcionais e avaliação do desempenho". 1o Congresso Nacional de Argamassas de Construção, Lisboa, LNEC. 